\title{
Cytologic Variants of $\gamma \delta$ T Cell Lymphoma in Cattle
}

\author{
Mitsuru ITO $^{1)}$, Midori KUBO ${ }^{2)}$, Hiroaki TAKAYAMA ${ }^{3)}$, Yoshiharu ISHIKAWA ${ }^{4)}$ and Koichi KADOTA ${ }^{4) *}$ \\ ${ }^{1)}$ Tokachi Livestock Hygiene Service Center, 59-6 Kisen, Kawanishi, Obihiro 089-1182, ${ }^{2)}$ Kamikawa Livestock Hygiene Service Center, \\ 4-15 Higashitakasu, Asahikawa 071-8154, ${ }^{3}$ Rumoi Livestock Hygiene Service Center, 6 Motomachi, Horonobe 098-3217 and \\ ${ }^{4)}$ Hokkaido Research Station, National Institute of Animal Health, 4 Hitsujigaoka, Toyohira, Sapporo 062-0045, Japan
}

(Received 25 August 2010/Accepted 18 October 2010/Published online in J-STAGE 1 November 2010)

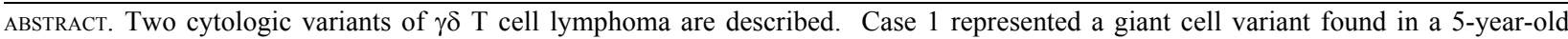
Holstein cow, which had large tumor masses in the pelvic cavity. This variant consisted of very large lymphoid cells with round to oval nuclei, medium-sized nucleoli and abundant cytoplasm. Case 2 was an aborted 7-month-old female Holstein fetus, which represented an immature cell variant. Most of the neoplastic lesions were located in the skin and pleural and peritoneal submesothelial tissues. The neoplastic tissues were composed of homogeneous growth of lymphoma cells characterized by inconspicuous nucleoli and finely dispersed chromatin. Both cases demonstrated CD3, CD8 and WC1 immunoreactivity. The current study revealed that there are 4 cytologic variants (common, giant cell, hypergranular and immature cell) in bovine $\gamma \delta \mathrm{T}$ cell lymphomas.

KEY WORDS: $\gamma \delta$ T cell lymphoma, cattle, CD8.

J. Vet. Med. Sci. 73(3): 399-402, 2011

The number of $\gamma \delta \mathrm{T}$ cells in cattle is very high, which is striking compared with the low proportion of $\gamma \delta$ T cells found in humans [3]. Although human $\gamma \delta \mathrm{T}$ cell lymphoma is rare, hepatosplenic $\gamma \delta$ T cell lymphoma is established as a distinct clinicopathologic entity [4], and the tumor cells have a nonactivated cytotoxic $\mathrm{T}$ cell immunophenotype. In contrast, $\gamma \delta \mathrm{T}$ cell lymphomas involving mucosal surfaces or skin have an activated cytotoxic phenotype [16].

In cattle, $\gamma \delta \mathrm{T}$ cell lymphoma is characterized by $\mathrm{WC} 1$ expression, and most cases have neoplastic lesions chiefly in extranodal sites such as the skin, intestine, uterus, abdominal cavity and meninges $[1,8,10,14]$, though a case of nodal $\gamma \delta \mathrm{T}$ cell lymphoma has been reported [14]. Unlike the most common form of cutaneous lymphoma, which is one of 4 forms of bovine leukosis [15], cutaneous $\gamma \delta \mathrm{T}$ cell lymphoma may be accompanied with epitheliotropic neoplastic infiltrates in various internal organs $[7,13]$. Bovine $\gamma \delta \mathrm{T}$ cell lymphomas are usually composed of lymphoid cells that are monomorphic and large in size with relatively abundant cytoplasm (common variant) [10]. However, a case of hypergranular $\gamma \delta \mathrm{T}$ cell lymphoma has been recorded in a heifer [11], and the neoplastic cells are cytologically distinct from those of the common variant, in which cytoplasmic granules are not detectable at the light microscopy level [14]. Here we describe 2 additional variants of bovine $\gamma \delta \mathrm{T}$ cell lymphoma that could be cytologically distinguished from the common and hypergranular variants.

Case 1 is a 5-year-old Holstein cow, which experienced anorexia, fever, anemia (hematocrit, 18.2\%) and enlargement of some superficial lymph nodes. Five days later, an agar gel immunodiffusion test for antibodies to bovine leu-

\footnotetext{
* Correspondence to: Kadota, K., Hokkaido Research Station, National Institute of Animal Health, 4 Hitsujigaoka, Toyohira, Sapporo 062-0045, Japan.

e-mail:kkadota@affrc.go.jp
}

kosis virus (BLV) [9] was performed with negative results, but blood examination showed a white blood cell count of $9,800 / \mu l$ with $27 \%$ lymphocytes, $10 \%$ atypical lymphocytes, $56 \%$ neutrophils and $7 \%$ eosinophils. In addition, rectal examination revealed intra-abdominal tumor masses. The cow deteriorated gradually and was euthanized 25 days after the onset of clinical signs. Postmortem examination revealed marked enlargement of the parotid, mandibular and mammary lymph nodes on the left side, and slight enlargement on the right side. Some lymph nodes in the left cervical region were also enlarged, and swelling of the left subiliac lymph node was mild. In the pelvic cavity, there were 2 tumor masses which were adherent to the adipose capsule: an exceedingly large tumor mass, $50 \times 30 \times 20 \mathrm{~cm}$ in size, and a smaller one, $20 \times 15 \times 15 \mathrm{~cm}$. The mesenteric lymph nodes were also greatly enlarged.

Case 2 was an aborted 7-month-old female Holstein fetus. White tumor nodules $1 \mathrm{~cm}$ in diameter were dispersed throughout the body surface. There were multiple tumor nodules up to $1 \mathrm{~cm}$ in the lungs, and similar ones were scattered on the surfaces of the spleen and liver as well as on their cut surfaces. Several nodules up to $1 \mathrm{~cm}$ were also observed on the abomasal serosa. Nodules $1 \mathrm{~cm}$ in diameter were found on the thymus, parietal pleura, parietal peritoneum and omentum, and in the placenta as well. A $2 \mathrm{~mm}$ nodule was detected on the cut surface of the tongue. No enlarged lymph nodes were detected.

Tissues were fixed in $10 \%$ buffered formalin, embedded in paraffin, sectioned at $4 \mu \mathrm{m}$, and stained with hematoxylin and eosin (HE). Immunohistochemistry was performed by the streptoavidin-biotin complex/horseradish peroxidase (SAB-PO) method on histologic sections using Histofine SAB-PO kits (Nichirei, Tokyo, Japan). The primary antibodies utilized were rabbit polyclonal antibodies to human CD3 (Dako A/S, Glostrup, Denmark), human CD5 (Lab Vision, Fremont, CA, U.S.A.) and bovine terminal deoxy- 

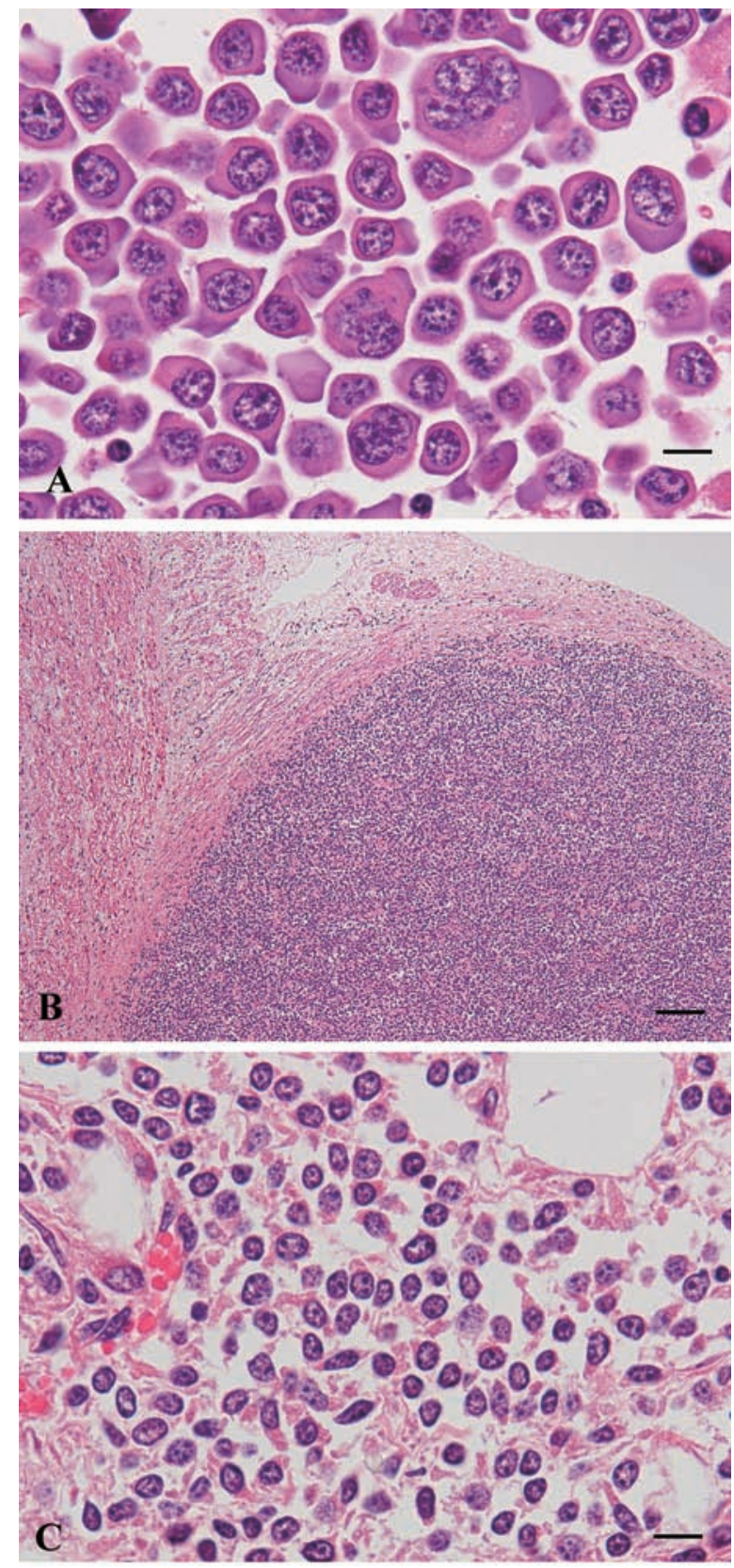

Fig. 1. Histology of neoplastic lesions. (A) Case 1, mesenteric lymph node. Large lymphoma cells, some of which show multinuclear forms, are present within the greatly expanded lymph sinus. HE. Bar $=10 \mu \mathrm{m}$. (B) Case 2, abomasum. The neoplastic tissue is localized in the subserosal tissue. The muscle coat is on the left. HE. Bar= $100 \mu \mathrm{m}$. (C) Case 2, subcutis. The lymphoma cells are characterized by relatively small size and inconspicuous nucleoli. HE. Bar $=10 \mu \mathrm{m}$.

nucleotidyl transferase (TdT) (Dako Corporation, Carpinteria, CA, U.S.A.), and mouse monoclonal antibodies to human CD79a (Dako A/S), human perforin (Sumitomo Electric Industries, Osaka, Japan), bovine WC1-N3 (Veteri-
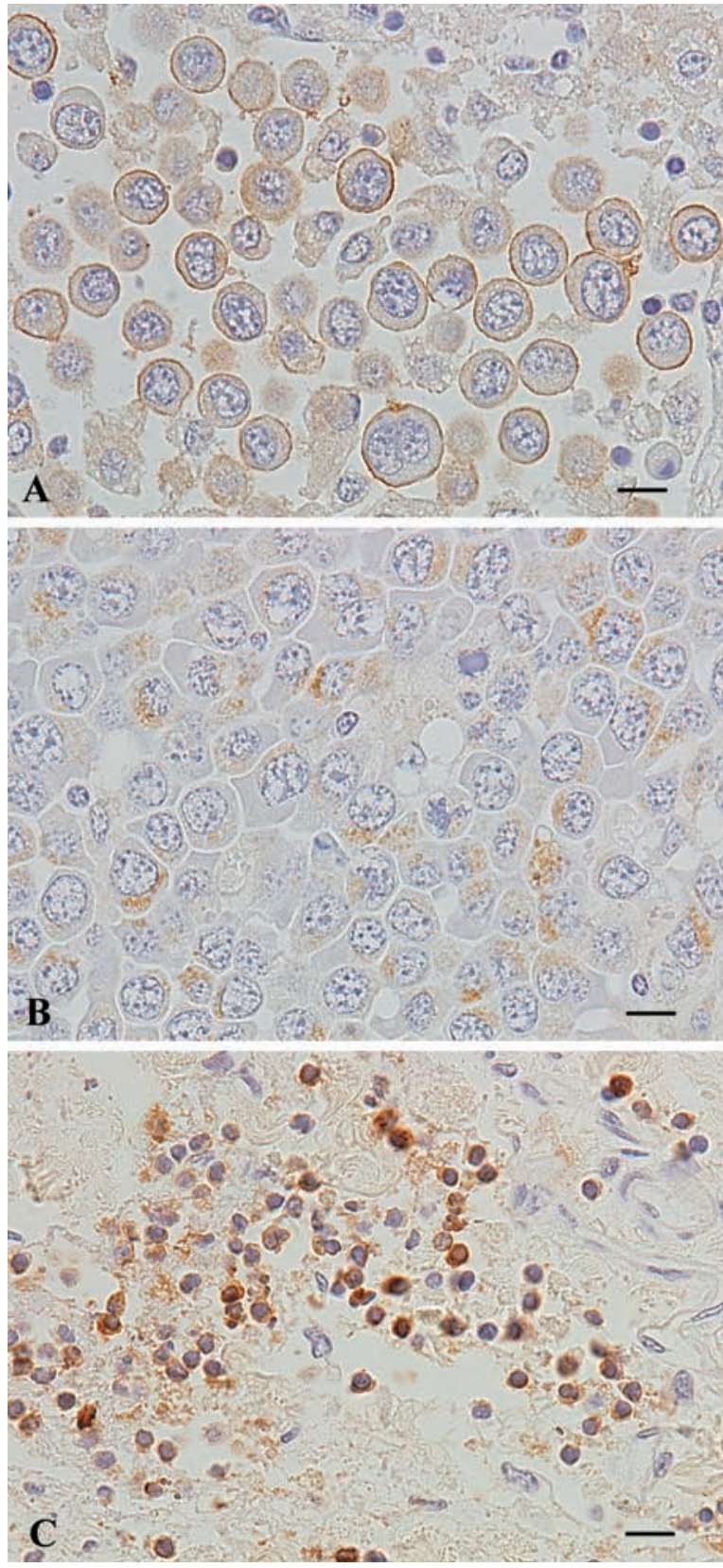

Fig. 2. Immunohistochemistry of neoplastic cells. (A) Case 1, mesenteric lymph node. Large lymphoma cells show surface membrane staining for CD8. SAB-PO. Bar $=10 \mu \mathrm{m}$. (B) Case 1, mesenteric lymph node. Perforin is expressed in many neoplastic cells. SAB-PO. Bar $=10 \mu \mathrm{m}$. (C) Case 2, subcutis. CD3 positivity is visible in the majority of neoplastic cells. SAB-PO. Bar $=10 \mu \mathrm{m}$.

nary Medical Research and Development, Pullman, WA, U.S.A.) and bovine CD8 (AbD Serotec, Oxford, U.K.). In order to examine CD8 expression, 9 previously reported [1, $7,8,10,11,13,14]$ and 5 additional cases of WC1-positive $\gamma \delta \mathrm{T}$ cell lymphoma (13 common and one hypergranular 
variants) were investigated immunohistochemically.

Histologically, the intra-abdominal masses in case 1 consisted of neoplastic tissues with widespread areas of necrosis and/or hemorrhage, in which closely packed neoplastic cells grew in sheets or nests separated by connective tissue septae. In the severely enlarged lymph nodes, many neoplastic cells were within dilated lymph sinuses, and the remaining intersinusoidal lymphatic tissues were compressed and reduced to extremely thin columns. There were no neoplastic tissues in the spleen, liver, kidneys, lungs and bone marrow. The tumor cells were very large in size, ranging 9-33 $\mu \mathrm{m}$ in diameter, with ample amount of amphophilic or lightly basophilic cytoplasm. The nuclei were round, oval or mildly irregular, with medium-sized nucleoli and moderately condensed chromatin. Larger cells tended to contain multiple nuclei (Fig. 1A). The mitotic count ranged from 22 to 36 per high-power field (HPF).

In case 2, most of the cutaneous lesions were located just beneath the epidermis with obliteration of dermal appendages. The overlying epidermis was thin and atrophic, and was invaded by a few tumor cells. In the thoracic and abdominal cavities, neoplastic tissues were mainly in the submesothelium (Fig. 1B), but in the abomasum, some were in the submucosa with rare extension into the lamina propria. Similar neoplastic tissues were also seen in the interstitium of the lungs and liver, the chorioallantoic membrane, and the muscle layer of the tongue. Most lymphoma cells were homogeneous in shape and measured 4-9 $\mu \mathrm{m}$ in diameter (Fig. 1C), but larger cells up to $12 \mu \mathrm{m}$ were detected extremely rarely. The cells had round to oval nuclei with finely dispersed chromatin, which were surrounded by a relatively narrow rim of cytoplasm. The nucleoli were inconspicuous or sometimes moderate in size. Mitotic figures were plentiful (HPF, 14-23).

Immunohistochemically, the tumor cells in case 1 were positive for CD3, CD5, CD8 (Fig. 2A) and WC1, and perforin-positive neoplastic cells were also frequently observed (Fig. 2B). Serial sections demonstrated colocalization of CD8 and WC1 in the neoplastic cells. In case 2, CD3- (Fig. 2C), CD8- or WC1-positive neoplastic cells were detected. Immunohistochemical analysis for the other markers was impossible due to complete loss of immunoreactivity caused by postmortem changes. CD8 expression by neoplastic cells was observed in all of the common and hypergranular variant cases.

In cattle, $\gamma \delta \mathrm{T}$ cell lymphoma is characterized by expression of $\mathrm{WC} 1$ and perforin, consisting of monomorphic large lymphoid cells with round to oval nuclei and relatively abundant cytoplasm $[1,7,8,10,13,14]$. The cells usually have no cytoplasmic granules at the light microscopy level (common variant), though a hypergranular variant has been reported [11]. Except in cell size, case 1 cytologically and immunophenotypically resembled the common type, and was categorized as a giant cell variant. Giant cells may also be observed in immunoblastic lymphoma and BLV-associated pleomorphic lymphoma, but these are cytologically characterized by the presence of a single prominent central nucleolus, and by marked pleomorphism and atypia, respectively [10].

Although TdT could not be demonstrated in case 2 because of postmortem changes, the neoplastic cells resembled those of precursor B-1 B cell lymphoma in newborn calf [17]. As in their adult counterparts [1], both case 2 and B cell lymphoma had intra-abdominal tumors, although the tumors were in the subserosal tissues with extension toward the mucous membrane in case 2 , and on the serosal surfaces with invasion into the mesentery in the B cell lymphoma. The neoplastic cells in the lymphomas were also similar to those in thymic $\mathrm{T}$ and $\mathrm{B}$ cell lymphomas [8, 10, 18], and these 4 types of lymphoma may be similar at the stage of lymphocyte differentiation. On the basis of the immature cell morphology and $\mathrm{WC} 1$ expression, case 2 was classified as an immature cell variant of $\gamma \delta \mathrm{T}$ cell lymphoma.

In normal bovine tissues, the major subsets of $\gamma \delta \mathrm{T}$ cells are generally considered to be WC1-positive and CD8-negative, or WC1-negative and CD8-positive [12]. However, the presence of $\mathrm{WC} 1$ and CD8 was also demonstrated in frozen sections of a bovine $\gamma \delta \mathrm{T}$ cell lymphoma [13]. In addition, the current study demonstrated the expression of CD8 in all WC1-positive cases examined. Since there are WC1and CD8-positive lymphocytes in normal intestinal epithelium (unpublished data), colocalization of these 2 markers in neoplastic cells should not be regarded as aberrant expression caused by neoplastic transformation [6]. Thus, studies on $\mathrm{T}$ cell tumors throw light on features of their normal counterparts [5], and the tissue distribution of neoplastic lesions in case 2 may reflect normal bovine $\gamma \delta \mathrm{T}$ cell development during fetal life.

The World Health Organization classification of human lymphoid neoplasms is not directly applicable to bovine neoplasms and requires certain modifications $[6,10]$. The large population of $\gamma \delta$ T cells in cattle implies that development of malignancy is not infrequent. In bovine $\gamma \delta \mathrm{T}$ cell lymphomas, there are cases showing epitheliotropism in the skin and various mucosae $[7,13]$, and the neoplastic cells, except in the immature cell variant, are large and uniform in shape $[7,11,13]$. In humans, the hepatosplenic type is the most common $\gamma \delta \mathrm{T}$ cell lymphoma, although other types involving either skin, intestine or nasal region have also been detected [16]. In the nonhepatosplenic lymphomas, the neoplastic cells are pleomorphic and vary in size among patients $[2,16]$. The tissue distribution and histologic features of human $\gamma \delta \mathrm{T}$ lymphomas $[2,16]$ are quite different from those of bovine cases $[1,7,13]$, which may be due to differences in function between human and bovine $\gamma \delta \mathrm{T}$ lymphocytes.

\section{REFERENCES}

1. Abe, Y., Shoji, H., Ota, K., Takahashi, M., Katsuragi, K., Takeda, Y., Nakamura, K., Ishikawa, Y. and Kadota, K. 2007. Immunohistochemical study of lymphomas of abdominal cavity origin in two cows with bovine leukemia virus. Jpn. Agric. Res. Quart. 41: 153-156.

2. Arnulf, B., Copie-Bergman, C., Delfau-Larue, M.-H., 
Lavergne-Slove, A., Bosq, J., Wechsler, J., Wassef, M., Matuchansky, C., Epardeau, B., Stern, M., Bagot, M., Reyes, F. and Gaulard, P. 1998. Nonhepatosplenic $\gamma \delta$ T-cell lymphoma: a subset of cytotoxic lymphomas with mucosal or skin localization. Blood 91: 1723-1731.

3. Goddeeris, B. 1998. Immunology of cattle. pp. 439-484. In: Handbook of Vertebrate Immunology (Pastret, P.-P., Griebel, P., Bazin, H. and Govaerts, A. eds.), Academic Press, San Diego.

4. Jaffe, E. S. and Ralfkiaer, E. 2001. Hepatosplenic T-cell lymphoma. pp. 210-211. In: Pathology and Genetics of Tumours of Haematopoietic and Lymphoid Tissues (Jaffe, E. S., Harris, N. L., Stein, H. and Vardiman, J. W. eds.), IARC Press, Lyon.

5. Janeway, C. A. Jr., Travers, P., Walport, M. and Shlomchik, M. 2005. The development and survival of lymphocytes. pp. 241316. In: Immunobiology, 6th ed., Garland Science, New York.

6. Kadota, K. 2010. Lymphoma. pp. 56-59. In: Systemic Animal Pathology, 2nd ed. (Umemura, T., Okada, K., Shirota, K., Taniyama, H., Nakayama, H. and Hayashi, T. eds.), Buneido, Tokyo (in Japanese).

7. Kadota, K., Wada, Y., Ishikawa, Y. and Shibahara, T. 2001. $\gamma \delta$ T-cell lymphoma with tropism for various types of epithelium in a cow. J. Comp. Pathol. 124: 308-312.

8. Kagawa, Y., Tomita, K., Nakatani, H., Sato, K., Wada, Y., Ishikawa, Y. and Kadota, K. 2009. Immunohistochemical characterization of five types of lymphoid neoplasms in calves. Jpn. Agric. Res. Quart. 43: 239-245.

9. Kono, Y., Sentsui, H., Miyamoto, T., Morozumi, K. and Sakamoto, Y. 1982. Changes in antibody titers in cattle infected clinically and subclinically with bovine leukemia virus. Int. J. Cancer 30: 655-657.

10. Murayama, S., Sato, K., Ikehata, T., Wada, Y., Ishikawa, Y. and Kadota, K. 2011. Cytologic and immunophenotypic investigation of lymphohematopoietic neoplasms in cattle. Jpn. Agric. Res. Quart. (in press).

11. Naitou, K., Ishikawa, Y. and Kadota, K. 2007. Hypergranular $\gamma \delta$ T-cell lymphoma in a heifer. Jpn. Agric. Res. Quart. 41: 7984.

12. Park, Y. H., Yoo, H. S., Yoon, J. W., Yang, S. J., An, J. S. and Davis, W. C. 2000. Phenotypic and functional analysis of bovine $\gamma \delta$ lymphocytes. J. Vet. Sci. 1: 39-48.

13. Sato, K., Shibahara, T. and Kadota, K. 2002. $\gamma \delta$ T-cell lymphoma in a cow. Aust. Vet. J. 80: 705-707.

14. Tanaka, H, Takai, H., Sato, K., Ishikawa, Y., Shibahara, T. and Kadota, K. 2003. Nodal, uterine and meningeal $\gamma \delta$ T-cell lymphomas in cattle. J. Vet. Med. A 50: 447-451.

15. Theilen, G. H. and Madewell, B. R. 1987. Bovine. pp. 408430. In: Veterinary Cancer Medicine, 2nd ed. (Theilen, G. H. and Madewell, B. R. eds.), Lea \& Febiger, Philadelphia.

16. Vega, F., Medeitos, L. J. and Gaulard, P. 2007. Hepatosplenic and other $\gamma \delta$ T-cell lymphomas. Am. J. Clin. Pathol. 127: 869880 .

17. Yamamoto, S., Wada, Y., Ishikawa, Y. and Kadota, K. 2007. Precursor B-1 B cell lymphoma in a newborn calf. J. Vet. Diagn. Invest 19: 447-450.

18. Yamazaki, Y., Ishikawa, Y., Shibahara, T., Kadota, K. and Ishino, S. 2000. An immunohistochemical and ultrastructural study of thymic lymphoma in a steer. Jpn. Agric. Res. Quart. 34: 195-198. 